\title{
Purinergic P2Y Receptors Are Involved in Xenopus Head Formation
}

\author{
Ayano Harata1, Haruka Nishida1,2, Akiha Nishihara1, Chikara Hashimoto ${ }^{1,2}$ \\ ${ }^{1}$ JT Biohistory Research Hall, Takatsuki, Japan \\ ${ }^{2}$ Department of Biological Sciences, Graduate School of Science, Osaka University, Toyonaka, Japan \\ Email: hashimoto@brh.co.jp
}

How to cite this paper: Harata, A., Nishida, H., Nishihara, A. and Hashimoto, C. (2016) Purinergic P2Y Receptors Are Involved in Xenopus Head Formation. CellBio, 5, 49-65.

http://dx.doi.org/10.4236/cellbio.2016.54004

Received: September 30, 2016

Accepted: December 23, 2016

Published: December 26, 2016

Copyright $\odot 2016$ by authors and Scientific Research Publishing Inc. This work is licensed under the Creative Commons Attribution International License (CC BY 4.0).

http://creativecommons.org/licenses/by/4.0/

\begin{abstract}
P2Y receptors belong to the family of G protein-coupled receptors and are activated by nucleotides in the extracellular space. We showed that Xenopus $P 2 Y 1$ and $P 2 Y 11$ were expressed in the dorsal marginal zone from early gastrula stage and enriched in the central nervous system from neurula stages. They were expressed in the prospective head region during early development. Knockdown of $P 2 Y 1$ and $P 2 Y 11$ caused head malformation, such as small eyes, brain atrophy, and defect in cartilage tissues, as well as reduced expression of neural, placode, and neural crest markers. Furthermore, the expression of neural plate and epidermal markers was affected by $P 2 Y 1$ or $P 2 Y 11$ depletion at early neurula stage, suggesting that $P 2 Y 1$ or $P 2 Y 11$ might be required for the neural induction. Our findings suggested that P2Y receptors might be involved in distinguishing between neural and non-neural fates. The results also suggested that $P 2 Y 1$ or $P 2 Y 11$ could play a role in neural induction and/or maintenance of neural tissues in the head formation processes.
\end{abstract}

\section{Keywords}

$P 2 Y 1, P 2 Y 11$, Xenopus laevis

\section{Introduction}

Purinergic signaling plays a crucial role in the nervous system, and its functions have been physiologically and pathophysiologically investigated [1] [2] [3]. The receptors of purine and pyrimidine are divided into adenosine (P1) receptors and adenosine triphosphate (ATP)/adenosine diphosphate (ADP) (P2) receptors. $\mathrm{P} 2$ receptors are composed of ionotropic $\mathrm{P} 2 \mathrm{X}$ and $\mathrm{G}$ protein-coupled $\mathrm{P} 2 \mathrm{Y}$ families. In mammals, eight $\mathrm{P} 2 \mathrm{Y}$ receptors, namely, $P 2 Y 1, P 2 Y 2, P 2 Y 4, P 2 Y 6$, 
$P 2 Y 11, P 2 Y 12, P 2 Y 13$ and $P 2 Y 14$, have been proven to be nucleotide receptors, and they have different molecular structures and selectivities to antagonist and agonist [3]. P2Y receptors are stimulated by nucleotides released in the extracellular space, after which they activate or inhibit phospholipase C (PLC) and adenylyl cyclase [2] [4]. In Xenopus laevis, six subtypes: $P 2 Y 1, P 2 Y 4, P 2 Y 10, P 2 Y 11$, $P 2 Y 12$ and $P 2 Y 13$, have been identified. Phylogenetic analysis showed that these subtypes could be divided into two subgroups: one group of $P 2 Y 1, P 2 Y 4$ and $P 2 Y 11$, the other group of $P 2 Y 10, P 2 Y 12$ and $P 2 Y 13$ (data not shown). Comparative analysis of amino acid sequences indicated that $X$. laevis $\mathrm{P} 2 \mathrm{Y}$ receptors were highly conserved among vertebrates, but not found in invertebrates. We expected that the emergence of $\mathrm{P} 2 \mathrm{Y}$ receptors might be related to the acquisition of new head of vertebrate.

$\mathrm{P} 2 \mathrm{Y}$ receptors participate in neuromodulation and neurotransmitter release, and are abundant in the central nervous system and the peripheral nervous system [5]. In $X$. laevis, $P 2 Y 1$ receptor and ectonucleoside triphosphate diphosphohydrolase (E-NTPD2) are synergistically involved in eye development [6]. $P 2 Y 11$ receptor is expressed during early development and enriched in the central nervous system [7], and is known to contribute to convergent extension during gastrulation [8]. Furthermore, intracellular $\mathrm{Ca}^{2+}$ increase is induced in supporting cells (SCs) of the main olfactory epithelium (MOE) through P2Y4 receptors [9] [10].

We were interested in the role of P2Y receptors in early development and evolution. $P 2 Y 1, P 2 Y 4$ and $P 2 Y 11$ belong to same subgroup and originate from the same ancestral gene; thus, they are expected to exhibit the same functions. In this study, we uncovered the expression patterns of $P 2 Y 1$ and $P 2 Y 11$ and their involvement in head formation in $X$. laevis embryos. $P 2 Y 1$ or $P 2 Y 11$ was observed in the prospective neuroectoderm and the dorsal marginal zone from early gastrula stage, and its expression was mainly enriched in the central nervous system and notochord. We found that $P 2 Y 1$ or $P 2 Y 11$ knockdown by morpholino antisense oligonucleotide (MO) led to head malformation. The disruption of $P 2 Y 1$ or $P 2 Y 11$ led to decreases in the expression of some neural, placode, and neural crest markers. Further, the morphant showed reduction of neural plate and enlargement of epidermis area at early neurula stage, suggesting that $P 2 Y 1$ or $P 2 Y 11$ might be required for cell fate specification in neural tissue.

\section{Materials and Methods}

\subsection{Embryo Manipulation and Injection}

Adult $X$. laevis was purchased from Watanabe Yosyoku (Hyogo, Japan) and embryos were obtained after artificial fertilization. Oocytes were obtained from female injected with 500 IU human chorionic gonadotropin (Sigma-Aldrich) 15 hours earlier, and fertilized with minced testis. Jelly coat was removed by $3 \%$ cysteine ( $\mathrm{pH}$ 8.0) treatment, and embryos were maintained in $10 \%$ Steinberg's 
solution (1x Steinberg's solution: $58 \mathrm{mM} \mathrm{NaCl}, 0.67 \mathrm{mM} \mathrm{KCl}, 0.34 \mathrm{mM}$ $\mathrm{Ca}\left(\mathrm{NO}_{3}\right)_{2} \cdot 4 \mathrm{H}_{2} \mathrm{O}, 0.83 \mathrm{mM} \mathrm{MgSO} \cdot \cdot 7 \mathrm{H}_{2} \mathrm{O}, 10 \mathrm{mM}$ HEPES, pH 7.3 at $\left.23^{\circ} \mathrm{C}\right)$ until the described stages. The developmental stages were determined according to [11]. For microinjection, mRNAs and MOs were injected into the dorsal animal blastomere of eight-cell-stage embryos. $\beta$-Galactosidase $(\beta$-Gal) $(400 \mathrm{pg})$ and yellow fluorescent protein (YFP) (400 pg) mRNAs were co-injected to confirm the injected region.

\subsection{Plasmid Construction and MO}

MOs were designed (Gene Tools) for the $P 2 Y 1$ or $P 2 Y 11$ transcript. The $P 2 Y 1$ MO sequence is 5'-gagagaaagacttctgtcatgatct-3' [6]; the $P 2 Y 11$ a MO sequence is 5'-ttgcagacggaggaagccatttatt-3'; the $P 2 Y 11 b \mathrm{MO}$ sequence is 5'-ttgcaggtgatggaagccattcttc-3'; and the COMO sequence is 5'-CCTCTTACCTCAGTTACAATTTATA-3'. Each MO (2 mM stock in sterilized water) was adjusted to the concentration of $0.4 \mathrm{mM}$, and $4 \mathrm{nl}$ of the solution was injected. P2Y11a and $P 2 Y 11 b$ likely represented alternative copies of the same genes. $P 2 Y 11 \mathrm{MO}$ is a 1:1 mixture of $P 2 Y 11 \mathrm{a} \mathrm{MO}$ and $P 2 Y 11 b \mathrm{MO}$. To confirm the injected region, $\beta$-Gal or YFP mRNA was co-injected. $\beta$-Gal activity of cytoplasmic lacZ was visualized with 5-bromo-4-chloro-3-indolyl- $\beta$-D-galactopyrano- side (X-gal, Wako).

\subsection{Whole-Mount in Situ Hybridization}

Embryos were collected and fixed in MEMFA [12], whole-mount in situ hybridization (WISH) was performed as previously described [13] with minor modifications. For the chromogenic reaction, nitro blue tetrazolium/5-bromo-4chloro-3-indolyl phosphate (NBT/BCIP, Roche) was used as the substrate of alkaline phosphatase. Embryo images were collected on a LEICA M2 FLIII microscope (Leica Microsystems). Antisense RNA probes for in situ hybridization were prepared from a template encoding anf1 [14], en2 [15], pax6 [16], foxE3 [17], 1-maf [18], rx1 [19], dlx5 [20], bfl [21], six6 [22], krox20 [23], n-cam [24] and $o t x 2$ [25]. pCS2AT+ containing $P 2 Y 1$ or $P 2 Y 11$ was constructed with the following primers: $P 2 Y 1-\mathrm{F}$ (5'-CCCCCTCGAGACCATGACAGAAGTCTTTCTCTCAGCT-3'); $P 2$ Y1-R (5'-CCCCGGCGCGCCTCACAAGCTTGTGTCCCCATTCTG-3'); $P 2$ Y11-F (5'-GGGATCGATCCACCATGGCTTCCTCCGTCTGCA-3') and $P 2 Y 11-\mathrm{R}$ (5'-GGGCTCGAGTTAAAGTCTACTCTCTCCTTGG-3'). Digoxigenin-labeled-antisense RNAs were generated by in vitro transcription with a MAXIscript Kit (Ambion) and an RNA Labeling Kit (Roche).

\subsection{Cartilage Staining}

Embryos at stage 45 were fixed in MEMFA and stained overnight in $0.2 \%$ alcian blue/30\% acetic acid in EtOH. After that, the embryos were washed with $80 \%$ glycerol/2\% $\mathrm{KOH}$. 


\subsection{TUNEL Assay}

Fixed embryos were rehydrated in PBS containing $0.1 \%$ Tween 20 and washed with terminal deoxynucleotidyltransferase (TdT) buffer (Takara) for $30 \mathrm{~min}$. End labeling was carried out at room temperature overnight in TdT buffer containing 2 uM digoxigenin-11-dUTP (Roche) and $150 \mathrm{U} / \mathrm{ml}$ TdT (Takara). Embryos were washed with $1 \mathrm{mM}$ EDTA in PBS for 1 hour and detected with NBT/BCIP.

\subsection{Histological Analysis}

Embryos were fixed with MEMFA overnight and dehydrated with $100 \% \mathrm{MeOH}$. The samples were embedded in paraffin (Pathoprep 568, Wako) and sectioned to 10 um thickness. The sections were deparaffinized and stained with hematoxylin and eosin.

\section{Results and Discussion}

\subsection{P2Y1 and P2Y11 Expression Patterns}

To analyze the spatial expression patterns of $P 2 Y 1$ and $P 2 Y 11$ during early development in Xenopus embryos, we performed whole-mount in situ hybridization. $P 2 Y 1$ was first detected in the animal hemisphere and the dorsal blastopore lip at early gastrula stage (Figure $1(\mathrm{~A})$ \& Figure $1(\mathrm{~B})$ ), and the expression was maintained in the prospective neuroectoderm and the involuting mesoderm at mid-gastrula stage (Figure $1(\mathrm{C})$ ). In neurulae, $P 2 Y 1$ expression was observed in the neural fold (Figure 1(D) \& Figure $1(\mathrm{G})$ arrowheads) and the anterior neural plate (Figure $1(\mathrm{E})$, Figure $1(\mathrm{~F})$, Figure $1(\mathrm{H})$ ), and $P 2 Y 1$ transcripts were also found in the notochord at mid-neurula stage (Figure 1(I)). At late neurula stage, $P 2 Y 1$ was detected in the central nervous system (Figure $1(\mathrm{~J})$, Figure $1(\mathrm{~K})$ ). Further, transverse sections showed that $P 2 Y 1$ localized to the dorsal structures, including the notochord and the area around the neural tube (Figure $1(\mathrm{~L})$ ). $P 2 Y 1$ localized to various head regions, including eye, otic vesicle, anterior neural tissues and migrating cranial neural crest cells (Figure $1(\mathrm{M})$ ). Thereafter, $P 2 Y 1$ was detected in the pallium, the dorsal domain of telencephalon, dorsal diencephalon, mesencephalon and metencephalon at tadpole stage (Figure $1(\mathrm{~N})$, Figure $1(\mathrm{O})$ ). The earliest $P 2 Y 11$ expression was also observed in the dorsal blastopore lip at early gastrula stage (Figure $2(\mathrm{~A})$ ), and a sagittal hemisection showed an expression pattern similar to $P 2 Y 1$ expression (Figure 2(B), Figure 2(C)). The $P 2 Y 11$ expression observed in the prospective neuroectoderm, the involuting mesoderm, and the central nervous system from gastrula to neurula stage had been reported previously [7]. $P 2 Y 11$ was expressed in the neural fold (Figure 2(D), Figure 2(G), arrowheads), the anterior neural plate (Figure 2(D), Figure 2(F), Figure 2(G), Figure 2(H)), and the posterior mesoderm (Figure 2(F)) at early-mid neurula stage, and in the entire central nervous system at late neurula stage (Figure $2(\mathrm{~J})$, Figure $2(\mathrm{~K})$ ). Further, transverse 

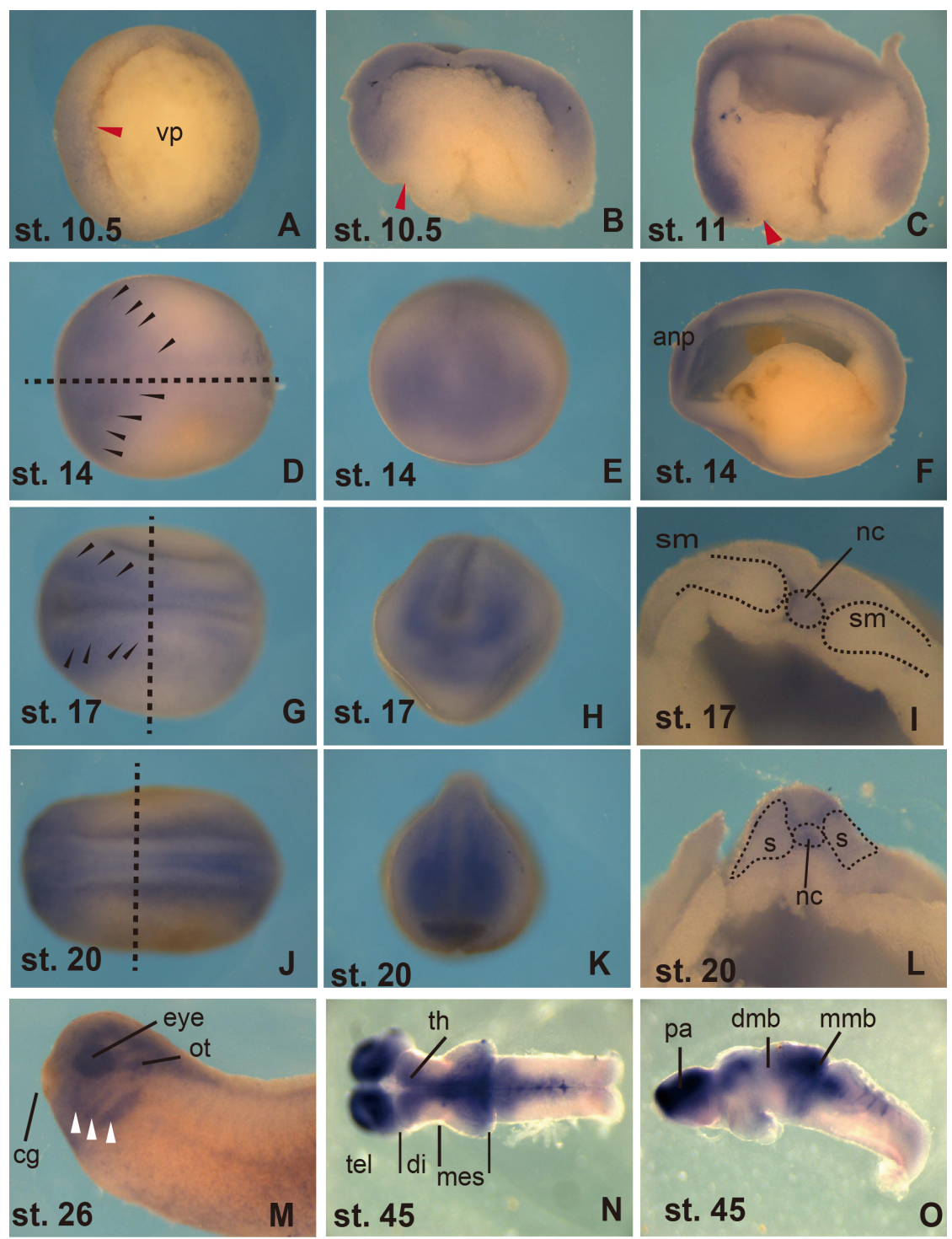

Figure 1. Expression pattern of $P 2 Y 1$ during early development. Whole mount in situ hybridization using DIG labeled $P 2 Y 1$ probe was performed on embryos from gastrula to tailbud stages. Stage10.5, vegetal view with dorsal blastopore (arrowhead) (A). Stage 10.5 (B) and 11 (C), sagitallyhemisections, with dorsal blastopore (arrowheads). P2 Y1 was expressed at the prospective neuroectoderm, the involuting dorsal and ventral mesoderm at gastrula stages. Stage 14 , dorsal view with head to the left (D), anterior view (E), sagitally section with head to the left (F). Stage 17, dorsal view with head to the left $(\mathrm{G})$, anterior view $(\mathrm{H})$, transverse section (I). Stage 20, dorsal view with head to the left $(\mathrm{J})$, anterior view $(\mathrm{K})$, transverse section (L). Stage 26, lateral view with head to the left $(\mathrm{M})$. The extirpated brain of tadpole $((\mathrm{N})$, dorsal side, $(\mathrm{O})$, left side). vp, vegetal pole; anp, anterior neural plate; sm, somitogenic mesoderm; s, somite; nc, notochord, cg, cement gland; ot, otic vesicle; tel, telencephalon; di, diencephalon; mes, mesencephalon; th, thalamus; pa, pallium (the dorsal domain of the telencephalon); dmb, diencephalon-mesencephalon boundary; mmb, mesencephalon-metencephalon boundary. Dotted straight line indicate section plane. Red arrowheads indicate blastopore. Black arrowheads indicate neural fold. White arrowheads indicate migrating neural crest cells. 

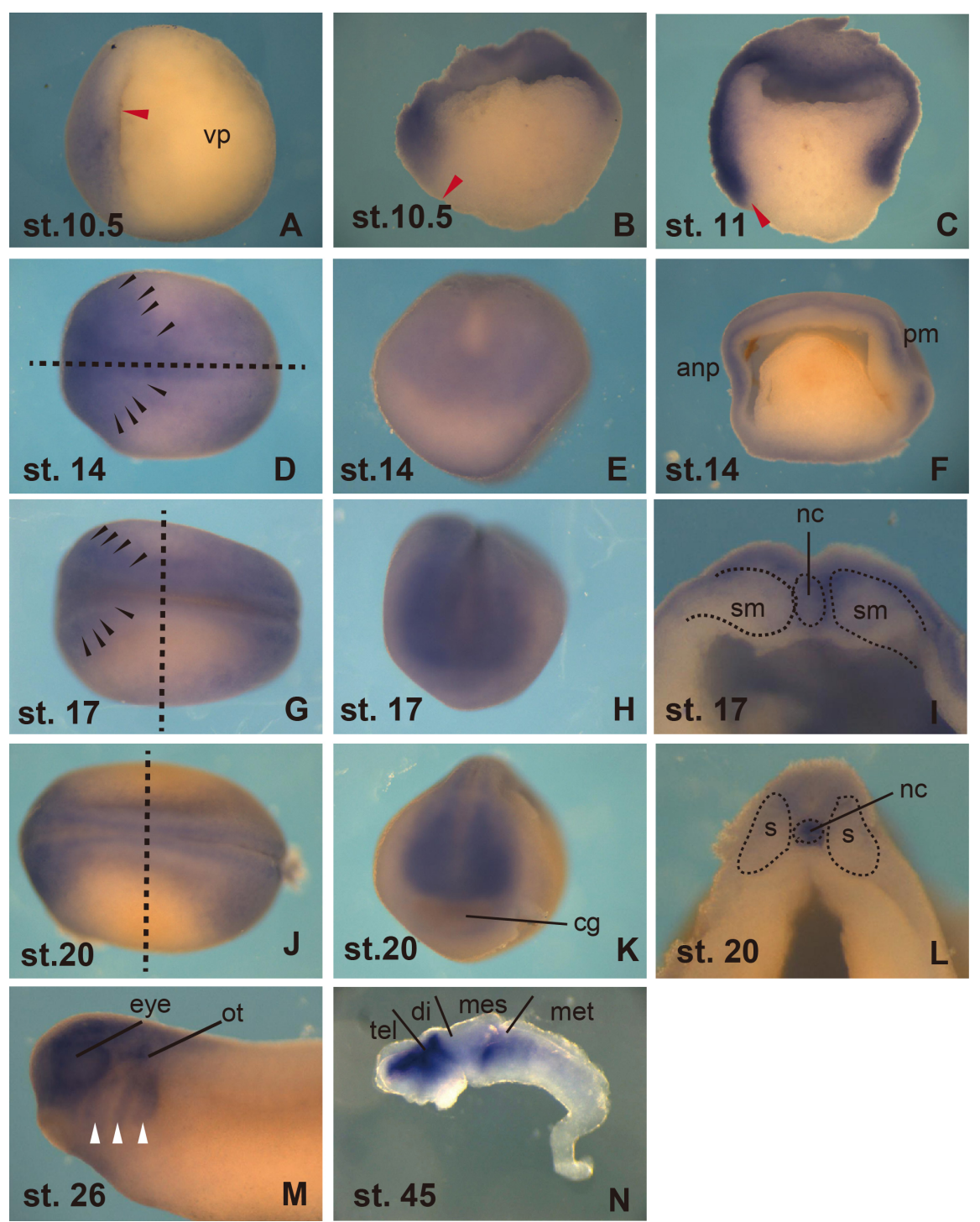

Figure 2. Expression pattern of $P 2 Y 11$ during early development. Whole mount in situ hybridization using DIG labeled $P 2 Y 11$ probe was performed on embryos from gastrula to tailbud stages. Stage 10.5, vegetal view with dorsal blastopore (arrowhead) (A). Stage 10.5 (B) and 11 (C), sagitallyhemisections, with dorsal blastopoe (arrowheads). Stage 14 , dorsal view with head to the left (D), anterior view (E), sagitally section with head to the left, (F). Stage 17, dorsal view with head to the left $(G)$, anterior view $(H)$, transverse section (I). Stage 20, dorsal view with head to the left $(J)$, anterior view $(\mathrm{K})$, transverse section (L). Stage 26, lateral view with head to the left $(\mathrm{M})$. The extirpated brain of tadpole ( $\mathrm{N}$, left side). vp, vegetal pole; anp, anterior neural plate; pm, posterior mesoderm; sm, somitogenic mesoderm; s, somite; nc, notochord; cg, cement gland; ot, otic vesicle; tel, telencephalon; di, diencephalon; mes, mesencephalon; th, thalamus; pa, pallium (the dorsal domain of the telencephalon); dmb, diencephalon-mesencephalon boundary; mmb, mesencephalon-metencephalon boundary. Dotted straight line indicate section plane. Red arrowheads indicate blastopore. Black arrowheads indicate neural fold. White arrowheads indicate migrating neural crest cells.

sections showed that $P 2 Y 11$ was expressed in the notochord and the peripheral 
area of the neural tube (Figure 2(I), Figure 2(L)). Thereafter, $P 2 Y 11$ was detected in the migrating cranial neural crest cells (Figure 2(M), arrowheads), the otic vesicle, and the anterior neural tissue at early tailbud stage. At tadpole stage, $P 2 Y 11$ localized to restricted parts of the brain, the telencephalon, the dorsal diencephalon, the mesencephalon, and the anterior metencephalon (Figure $2(\mathrm{~N})$ ). Thus, the expression of $P 2 Y 1$ and $P 2 Y 11$ during early development showed similar patterns, namely, they were predominantly detected in the head region and the notochord. Although little is known about the role of these genes in early development in $X$. laevis, it had been shown that E-NTDP2 and $P 2 Y 1$ synergistically regulated eye development [6] [26]. Moreover, $P 2 Y 11$ was expressed in the notochord and was important for convergent extension, coordinated cell polarization, and elevation of intracellular calcium in chordamesoderm cells [8]. These expression patterns indicated that $P 2 Y 1$ and $P 2 Y 11$ were expressed in vital areas and the head formation stages, suggesting that $P 2 Y 1$ and $P 2 Y 11$ might have the same functions, assisting each other in the same tissues, particularly in the head region.

\subsection{Depletion of $P 2 Y 1$ or P2Y11 Results in Head Malformation}

To investigate the role of $P 2 Y 1$ and $P 2 Y 11$ in head formation, we knocked down $P 2 Y 1$ or $P 2 Y 11$ by injecting MOs. $P 2 Y 1 \mathrm{MO}(13.6 \mathrm{ng}), P 2 Y 11 \mathrm{MO}$ (13.6 ng) or control MO (COMO: $29.9 \mathrm{ng}$ ) was injected with $\beta$-gal mRNA lineage tracer (400 pg) into one dorsal animal blastomere of 8-cell stage embryos. Embryos injected with $P 2 Y 1 \mathrm{MO}$ or $P 2 Y 11 \mathrm{MO}$ exhibited head malformation with small eyes (Figure 3(B), Figure 3(C), arrowheads), brain atrophy (Figure 3(H), Figure $3(\mathrm{I})$, arrowheads), and cartilage tissue defect (Figure 3(K), Figure 3(L), arrowheads), whereas those injected with COMO did not show head malformation (Figure 3(A), Figure 3(G), Figure 3(J), arrowheads). Further, histological sections of abnormal eyes in $P 2 Y 1 \mathrm{MO}$ or $P 2 Y 11 \mathrm{MO}$ injected embryos showed eye defects (Figure 3(E), Figure 3(F) arrowheads). These phenotypes could be divided into two groups: the severe group that showed serious eye defects, and the moderate group that showed slight malformation ( $P 2 Y 1$ MO: severe, 68.3\%, moderate, $29.3 \%, \mathrm{n}=41, P 2 Y 11 \mathrm{MO}$ : severe, $64.8 \%$, moderate, $29.6 \%, \mathrm{n}=54$ ). $P 2 Y 1$ or $P 2 Y 11$ knockdown resulted in similar head malformation at tadpole stage, suggesting that $P 2 Y 1$ and $P 2 Y 11$ could be involved in the same normal head formation process.

\subsection{Loss of $P 2 Y 1$ or $P 2 Y 11$ Function Affects Neural Gene Expression Patterns}

To analyze the effects of $P 2 Y 1$ or $P 2 Y 11$ depletion on Xenopus head formation in detail, we examined the expression of anterior neural marker genes (Figure 4). Embryos injected with $P 2 Y 1 \mathrm{MO}$ or $P 2 Y 11 \mathrm{MO}$ exhibited a significant decrease in the expression of fore to midbrain marker otx2 at mid-neurula stage (reduction in $P 2 Y 1$ MO: 60\%, $\mathrm{n}=20, P 2 Y 11 \mathrm{MO}: 66.7 \%, \mathrm{n}=18$, Figure 4(B) 

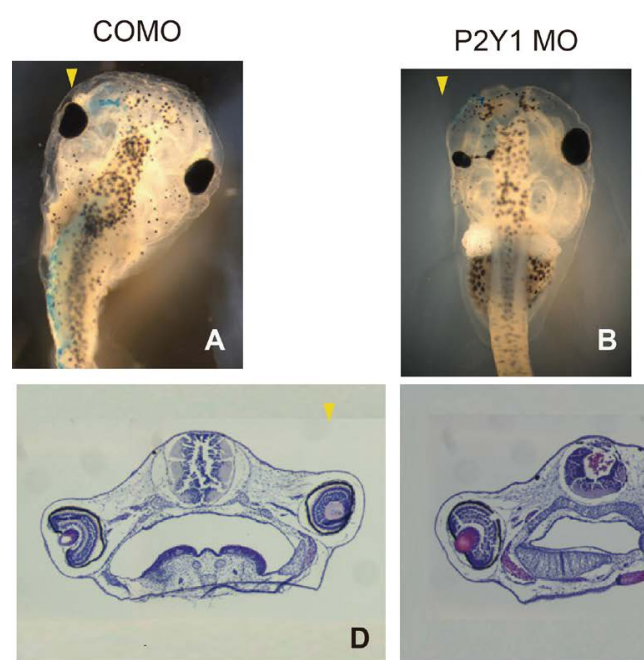

\section{P2Y11 MO}
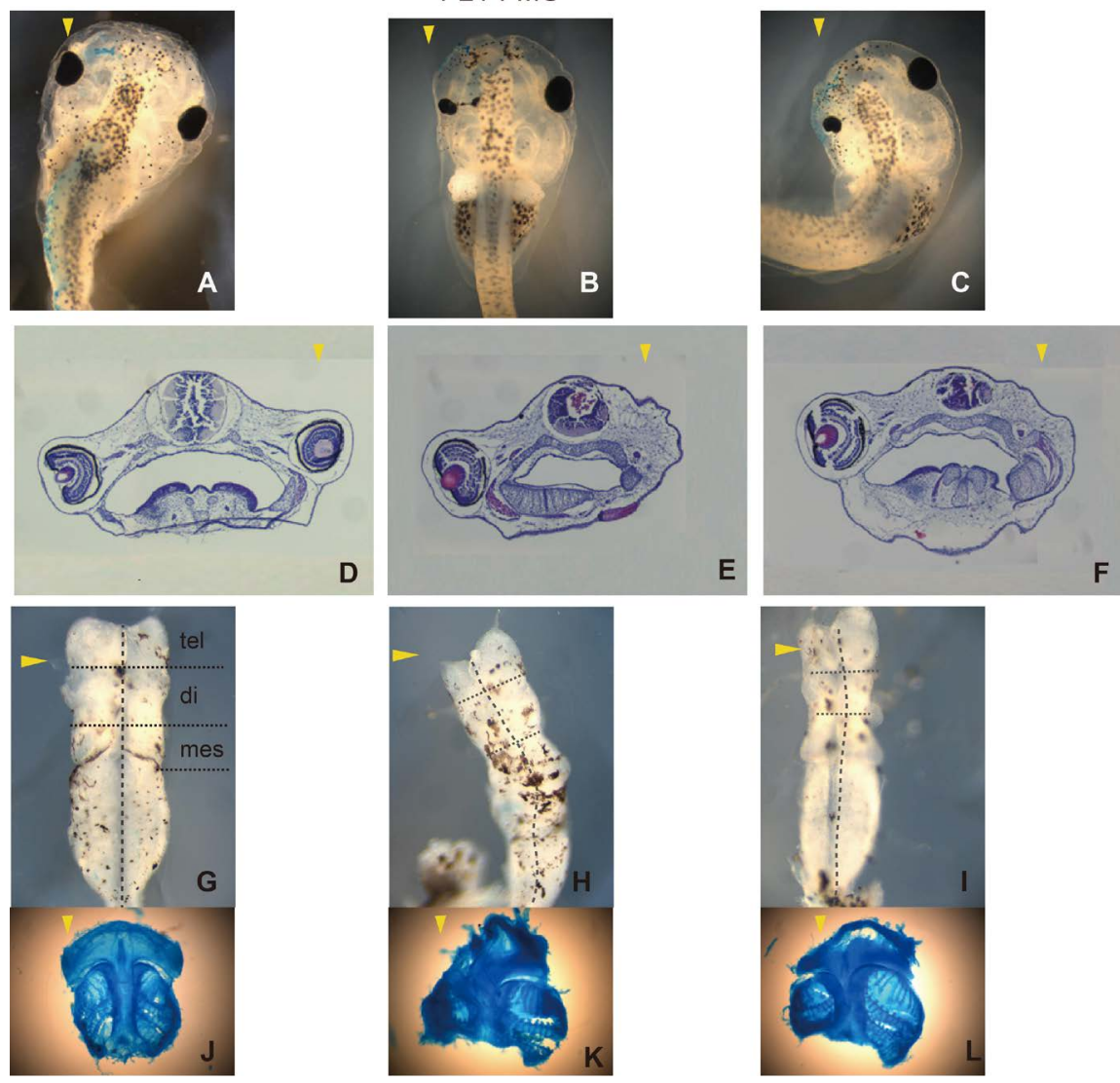

Figure 3. Depletion of $P 2 Y 1$ or $P 2 Y 11$ brings about head malformation. Phenotypes of tadpoles injected with COMO ((A), (D), (G), (J)), P2 Y1 MO ((B), (E), (H), (K)) or P2 Y11 MO ((C), (F), (I), (L)). COMO (29.9 ng), P2 Y1 MO (13.6 ng) or P2 Y11 MO (13.6 ng) was injected with $\beta$-gal mRNA as the lineage tracer into one dorsal animal cell of 8-cell stages. $\mathrm{X}$-gal staining was performing to identify the injected side (light blue). Embryos injected with $P 2 Y 1 \mathrm{MO}$ or $P 2 Y 11 \mathrm{MO}$ showed small eyes and the head malformation ((B), (C), arrowheads) at tadpole stage. The histological sections of small eye exhibited thin retinal layers and lens-like aggregates (E), (F). The extirpated brain of tadpoles (G)-(I). Cartilage tissues with alcian blue staining $(J)-(\mathrm{L})$. tel, telencephalon; di, diencephalon; mes, mesencephalon. Yellow arrowheads indicate the injected sides.

and Figure 4(C), arrowheads) and at late neurula stage ( $P 2 Y 1 \mathrm{MO}: 40 \%, \mathrm{n}=20$, $P 2 Y 11$ MO: 52.9\%, $\mathrm{n}=17$, Figure 4(E) and Figure 4(F), arrowheads). The expression of retinal maker pax6 was not significantly affected at mid-neurula stage (Figure $4(\mathrm{G})$, Figure $4(\mathrm{H})$, Figure $4(\mathrm{I})$ ), but was decreased at late neurula stage (reduction in $P 2 Y 1$ MO: 69.7\%, n = 33, $P 2 Y 11$ MO: 51.6\%, n = 31, Figure $4(\mathrm{~K})$ and Figure $4(\mathrm{~L})$, arrowheads). The expression of another retinal marker, $r x 1$, was slightly affected by the depletion of $P 2 Y 1$ or $P 2 Y 11$ (P2Y1 MO: $33.3 \%, \mathrm{n}=$ 21, $P 2 Y 11$ MO: 64\%, n = 25, Figure $4(\mathrm{~N})$ and Figure $4(\mathrm{O}))$ at stage 20. Further, at mid-neurula stage, the expression of hindbrain marker krox 20 , midbrainhindbrain boundary marker en2, and telencephalon marker bfl was markedly reduced in embryos injected with $P 2 Y 1$ or $P 2 Y 11 \mathrm{MO}(P 2 Y 1 \mathrm{MO}: 63 \%, \mathrm{n}=$ 


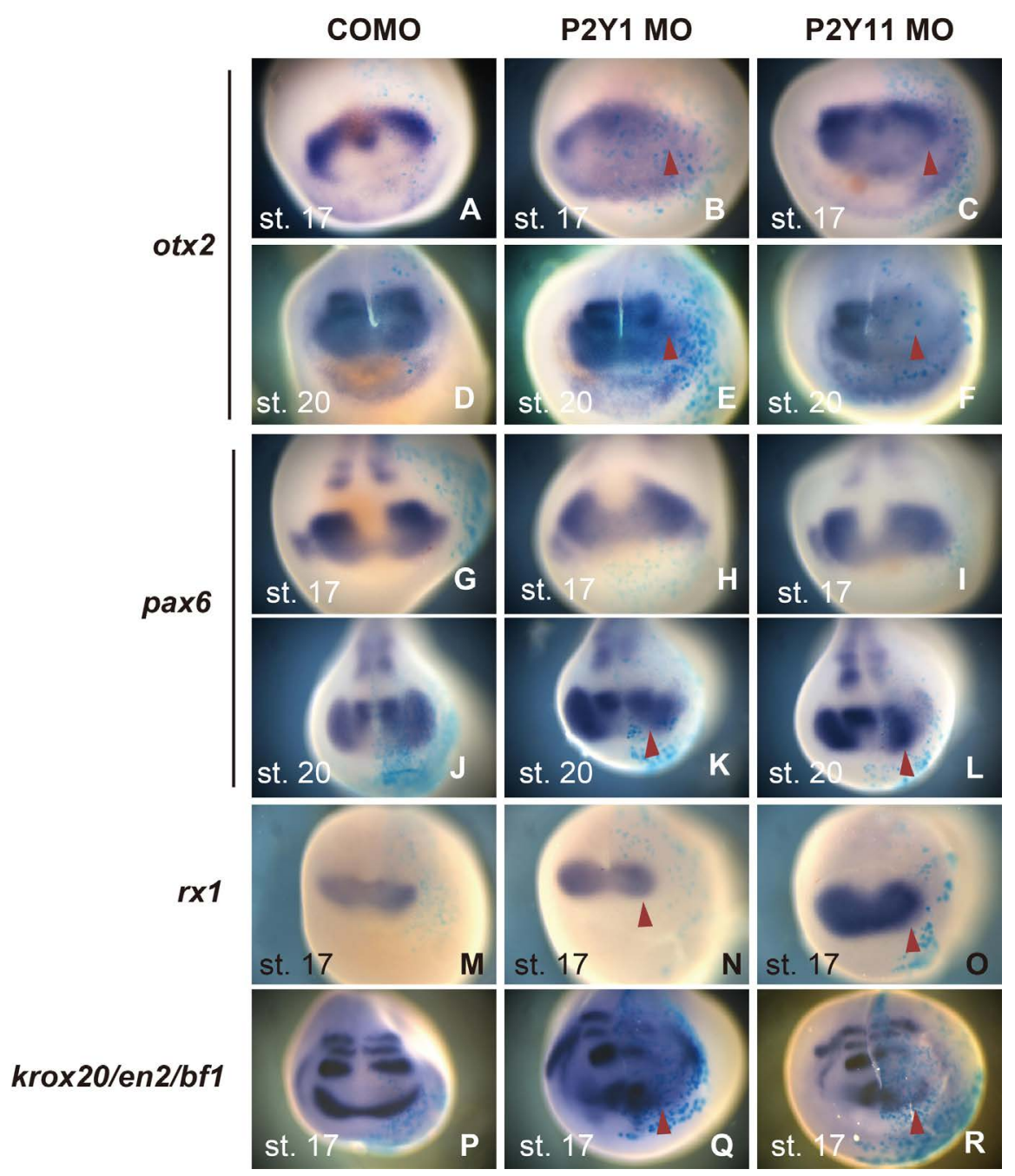

Figure 4. $P 2 Y 1$ or $P 2 Y 11$ knockdown cause abnormal anterior neural development. Embryos injected with COMO ((A), (D), (G), (J), (M), (P)), P2 Y1 MO ((B), (E), (H), (K), $(\mathrm{N}),(\mathrm{Q}))$ or $P 2 Y 11 \mathrm{MO}((\mathrm{C}),(\mathrm{F}),(\mathrm{I}),(\mathrm{L},(\mathrm{O}),(\mathrm{R}))$ were subjected to WISH for otx2 $((\mathrm{A})-(\mathrm{F}))$, pax6 ((G)-(L)), rx1 ((M)-(O)) and krox20/en2/bfl (P-R) at mid and late neurula stages. Microinjection and lineage tracing were performed as described in Figure 3. These anterior neural marker genes were decreased in the embryos injected with $P 2 Y 1$ MO or $P 2 Y 11 \mathrm{MO}$. All views show anterior views with injected side (blue; X-gal) facing rightward. Red arrowheads indicate reduction of marker gene expression.

11, $P 2 Y 11$ MO: 56\%, n = 16, Figure 4(Q), Figure 4(R), arrowheads). These data indicated that $P 2 Y 1$ or $P 2 Y 11$ knockdown affected the expression of anterior neural markers at neurula stage, consistent with the morphological phenotypes shown in Figure 3 (Figure 3(B), Figure 3(C), Figure 3(E), Figure 3(F), Figure 3(H), Figure 3(I)). As discussed earlier, $P 2 Y 1$ and $P 2 Y 11$ were expressed in the prospective dorsal region of the anterior neural plate (Figure $1(\mathrm{H})$, Figure $2(\mathrm{H})$ ) and localized to the dorsal diencephalon at tadpole stage (Figure $1(\mathrm{O})$, Figure $2(\mathrm{~N})$ ). It is known that ot 2 is expressed in the prospective dorsal diencephalon and pax6 is expressed in the ventral diencephalon at neurula stage [27]. 
Therefore, the results may be reasonable in that the depletion of $P 2 Y 1$ or $P 2 Y 11$ causes loss of otx 2 expression but has no effect on pax6 expression at mid-neurula stage. In the anterior neuroectoderm, anf is the earliest transcriptional repressor gene and plays a key role in rostral forebrain development [14] [28]. It is essential to inhibit the expression of two key regulators, ot $x 2$ and pax6, in the posterior forebrain [27]. Based on these reports, we attempted to investigate the effects of $P 2 Y 1$ or $P 2 Y 11 \mathrm{MO}$ on anfl expression. anfl was normally expressed in the prospective forebrain and the lens placode region at early neurula stage, and gradually localized to the prospective anterior pituitary at the end of neurulation [29]. anfl expression in embryos injected with $P 2 Y 1$ or $P 2 Y 11 \mathrm{MO}$ at early neurula stage did not show any significant difference $(P 2 Y 1$ MO: $\mathrm{n}=9, P 2 Y 11$ MO: $\mathrm{n}=12$, Figures $5(\mathrm{~A})-(\mathrm{C})$ ), but anfl expression increased laterally in the injected side at late neurula stage ( $P 2 Y 1 \mathrm{MO}: 87.5 \%, \mathrm{n}=16, P 2 Y 11 \mathrm{MO}: 76.5 \%$, $\mathrm{n}=17$, Figure $5(\mathrm{E})$ and Figure $5(\mathrm{~F})$, arrowheads). At early tailbud stage, anfl localized to the anterior pituitary upon $P 2 Y 1$ knockdown $(\mathrm{n}=45$, Figure $5(\mathrm{H}))$, although it did not localize to the pituitary $(93.3 \%, \mathrm{n}=15$, Figure $5(\mathrm{I})$, arrowhead) in the $P 2 Y 11 \mathrm{MO}$ injected side. In Xenopus embryo, anf overexpression can lead to enlargement of the rostral forebrain and inhibit genes that normally express in more posterior regions [14]. Moreover, anf functions as a
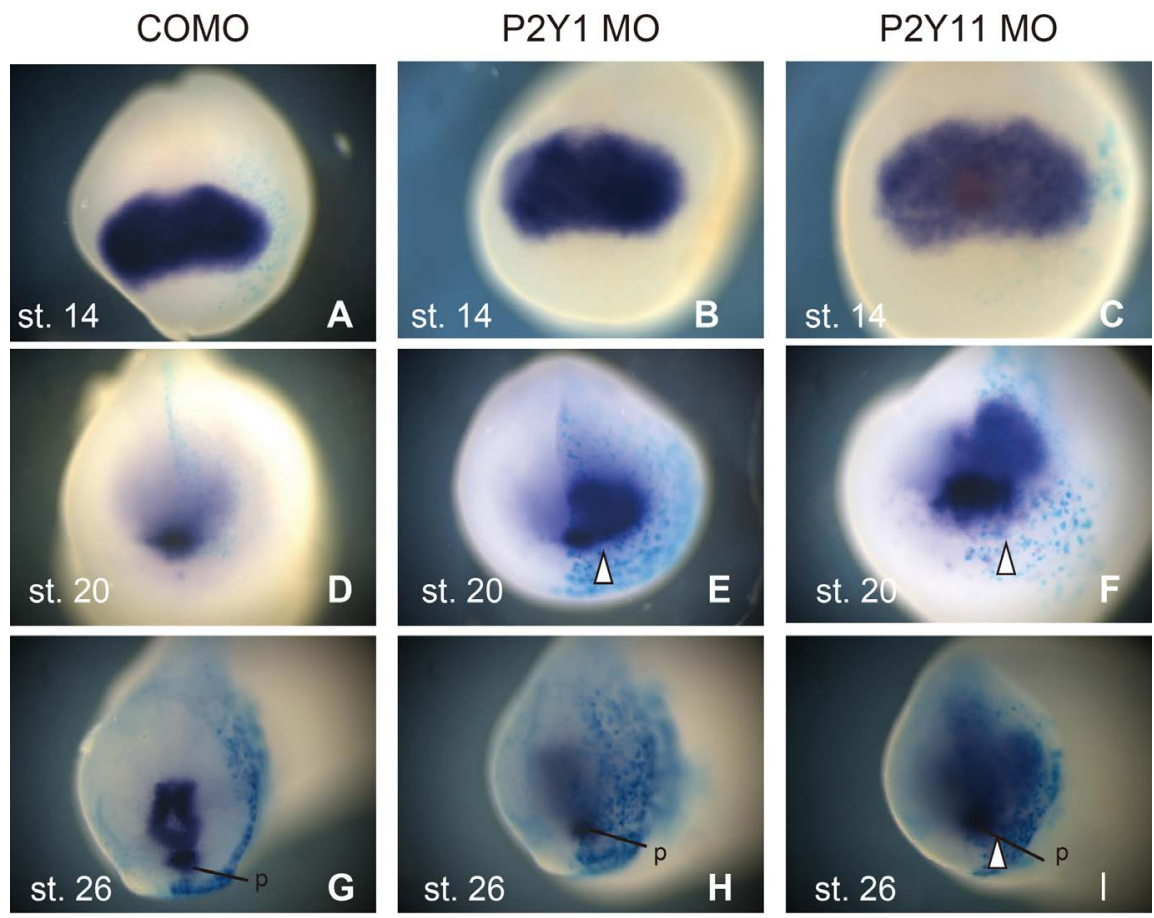

Figure 5. Depletion of $P 2 Y 1$ or $P 2 Y 11$ affects the localization of anfl expression. Embryos injected with COMO ((A), (D), (G)), P2 Y1 MO ((B), (E), (H)) or P2 Y11 MO ((C), $(F),(I))$ were analyzed for the expression of anflneurula and tailbud stages. Microinjection and lineage tracing were performed as described in Figure 3. Views are anterior with injected side (blue, X-gal) facing rightward. White arrowheads indicate expansion of anfl expression. p, pituitary. 
suppressor of posterior forebrain fate within the presumptive rostral forebrain and directly inhibits the expression of otx2 and pax6 in this area [27]. Thus, we speculated that ectopic anfl expression would repress otx 2 and pax6 expression during neurulation. At early tailbud stage, anfl localized to the pituitary in $P 2 Y 1$ morphants, whereas it did not localize to the pituitary in $P 2 Y 11$-depleted embryos (Figure 5(H), Figure 5(I)). Although $P 2 Y 1$ and $P 2 Y 11$ may play a similar role in head formation, it is likely that they have different regulation mechanisms. The expression domains of en 2 and krox 20 do not overlap with the anf1 expression area, and anfl cannot directly regulate the expression of $b f l$, which is co-expressed in a more anterior region of the neural plate [27]. Thus, we considered that the decrease in en2, krox 20 , and $b f 1$ expression might be independent of ectopic anfl expression. Together, our results demonstrated that the depletion of $P 2 Y 1$ or $P 2 Y 11$ led to loss of neural development as shown by the down-regulation of some neural marker genes.

\subsection{P2Y1 or P2Y11 Is Required for Placode and Neural Crest Development}

As the depletion of $P 2 Y 1$ or $P 2 Y 11$ resulted in lens malformation (Figure 3(E), Figure $3(\mathrm{~F})$ ), we examined the expression of lens placode marker genes, foxe3 and I-maf, at early tailbud stage (Figures 6(A)-(F)). The morphants showed reduced expression of foxe3 ( $P 2 Y 1$ MO: 71.9\%, $\mathrm{n}=32, P 2 Y 11 \mathrm{MO}: 65 \%, \mathrm{n}=13$, Figure 6(B) and Figure 6(C), arrowheads) and l-maf ( $P 2 Y 1 \mathrm{MO}: 7.1 \%, \mathrm{n}=14$, $P 2 Y 11$ MO: 73.3\%, $\mathrm{n}=15$, Figure 6(E) and Figure 6(F), arrowheads). Embryos injected with $P 2 Y 1$ or $P 2 Y 11 \mathrm{MO}$ showed significant reduction of pax6 expression in the lens placode region at late neurula stage (Figure $4(\mathrm{~K})$, Figure $4(\mathrm{~L})$, arrowheads). The lens field is lens-biased ectoderm within preplacodal ectoderm and is formed at mid-neurula stage in response to signals emitted from the adjacent anterior neural plate [30]. The reduction of pax6 and $r x 1$ expression suggested that insufficient induction from retina might bring about a defect in lens placode at neurula stage. In addition, we examined the expression of $d l x 5$, which marked the most cranial placode but not the lens placode, and detected a slight decrease in $d l x 5$ expression in $P 2 Y 1$ or $P 2 Y 11$ knockdown embryos ( $P 2 Y 1$ MO: 55.6\%, n = 18, $P 2 Y 11 \mathrm{MO}: 42.9 \%, \mathrm{n}=14$, Figure 6(H) and Figure 6(I), arrowheads). Furthermore, we examined the effect of $P 2 Y 1$ or $P 2 Y 11$ depletion on the expression of neural crest marker genes, snaill (Figures 7(A)-(L)) and foxD3 (data not shown), at neurula stage, because $P 2 Y 1$ or $P 2 Y 11$ knockdown resulted in a severe defect in cartilage tissues of neural crest derivatives. $P 2 Y 1$ or $P 2 Y 11$ knockdown rexpressed naill expression at early ( $P 2 Y 1 \mathrm{MO}: 75 \%, \mathrm{n}=8, P 2 Y 11$ MO: $80 \%, \mathrm{n}=10$, Figure $7(\mathrm{~B})$, Figure $7(\mathrm{C})$, arrowheads) and late ( $P 2 Y 1 \mathrm{MO}$ : $66 \%, \mathrm{n}=12, P 2 Y 11 \mathrm{MO}: 88 \%, \mathrm{n}=9$, Figure $7(\mathrm{E})$, Figure $7(\mathrm{~F})$, arrowheads) neurula stages, thereby resulting in the reduction of migrating neural crest cells ( $P 2 Y 1$ MO: $83 \%, \mathrm{n}=8, P 2 Y 11 \mathrm{MO}: 80 \%, \mathrm{n}=10$, Figure $7(\mathrm{~J})$, Figure $7(\mathrm{~L})$, asterisk). These results indicated that the loss of neural crest derivatives was caused 
COMO
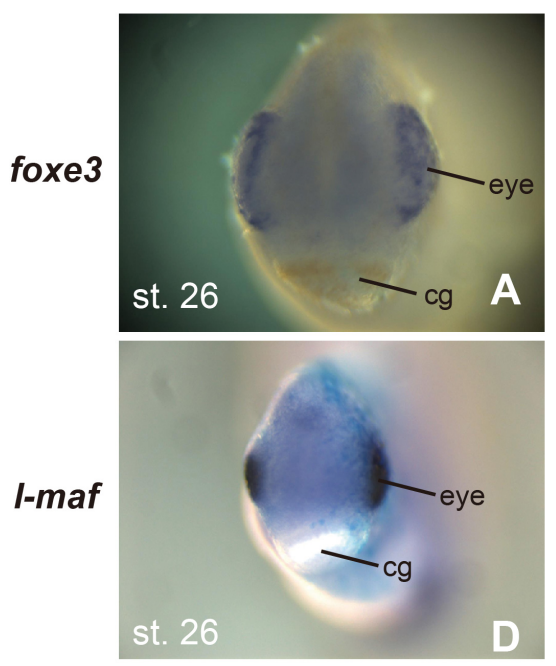

$d / x 5$

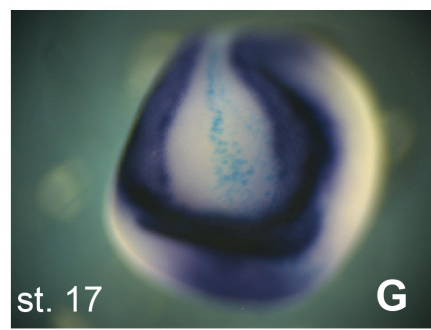

P2Y1 MO
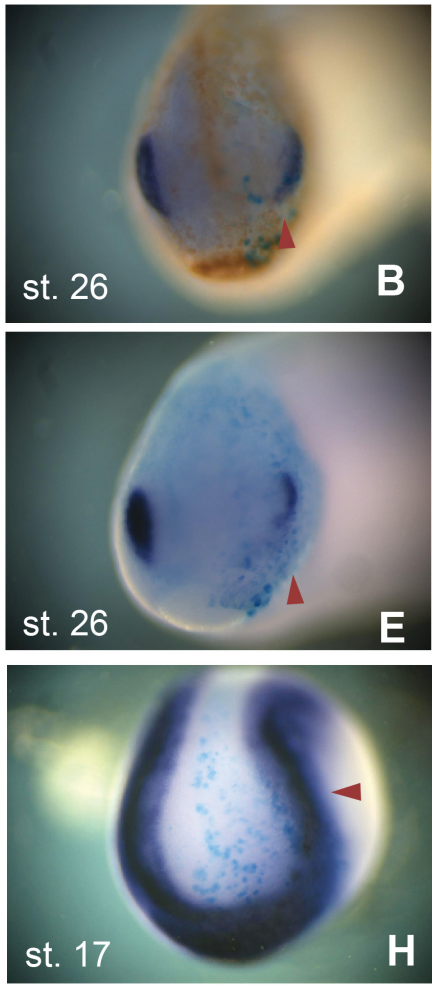

P2Y11 MO
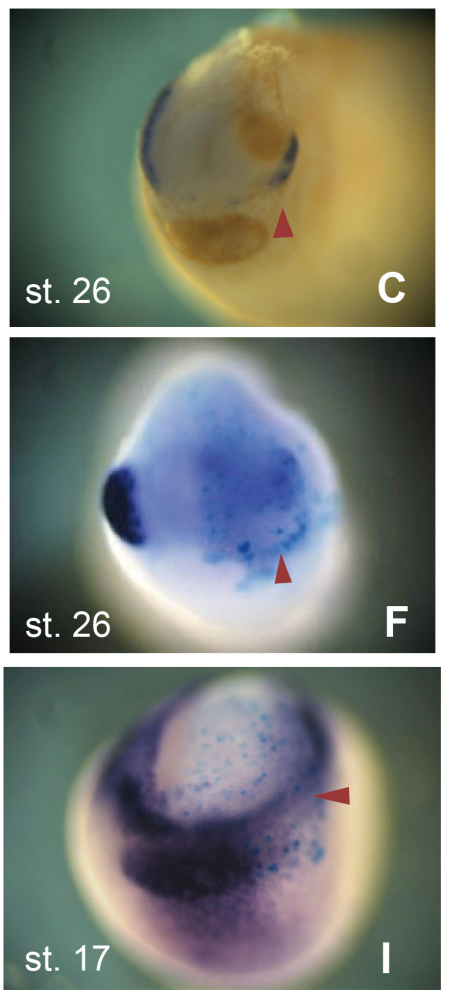

Figure 6. Embryos depleted $P 2 Y 1$ or $P 2 Y 11$ fail to produce the placode. Embryos injected with COMO ((A), (D), (G)), P2Y1 MO ((B), (E), (H)) or P2Y11 MO ((C), (F), (I)) were analyzed for the expression of foxe3 $((\mathrm{A})-(\mathrm{C}))$, l-maf $((\mathrm{D})-(\mathrm{F}))$ and $d l \times 5((\mathrm{G})-(\mathrm{I}))$ at tailbud stage. Microinjection and lineage tracing were performed as described in Figure 3. All views are anterior with injected side (blue, X-gal) facing rightward. Red arrowheads indicate reduction of marker gene expression. cg, cement gland.

by early hypoplasia of the neural crest region. Together, these data suggested that $P 2 Y 1$ or $P 2 Y 11$ might also be required for the entire head components, such as the placode and the neural crest cells.

\subsection{Loss of $P 2 Y 1$ or $P 2 Y 11$ Affects Induction or Maintenance of Neural Fate}

$P 2 Y 1$ or $P 2 Y 11$ was detected in the prospective neuroectoderm and the dorsal marginal zone from early gastrula stage (Figure 1, Figure 2), and snaill expression was affected by the depletion of $P 2 Y 1$ or $P 2 Y 11$ at early neurula stage (Figure $7(B)$, Figure $7(C)$ ). Therefore, we speculated that morphants affected developmental events occurring earlier than neurula stage. To identify the effects of $P 2 Y 1$ or $P 2 Y 11$ knockdown on neural fate at early neurula stage, we examined the expression of epidermal marker epi-keratin (Figures $8(\mathrm{~A})-(\mathrm{C})$ ) and neural plate marker NCAM (Figures $8(\mathrm{D})$-(F)) upon MO injection. We observed an enlargement of the area of epi-keratin expression ( $P 2 Y 1$ MO: $90.9 \%, \mathrm{n}=11$, $P 2 Y 11$ MO: $76.2 \%, \mathrm{n}=21$, Figure $8(\mathrm{~B})$ and Figure $8(\mathrm{C})$, yellow arrowheads) coupled with a decrease in the area of $N C A M$ expression ( $P 2 Y 1 \mathrm{MO}: 54.5 \%, \mathrm{n}=$ 


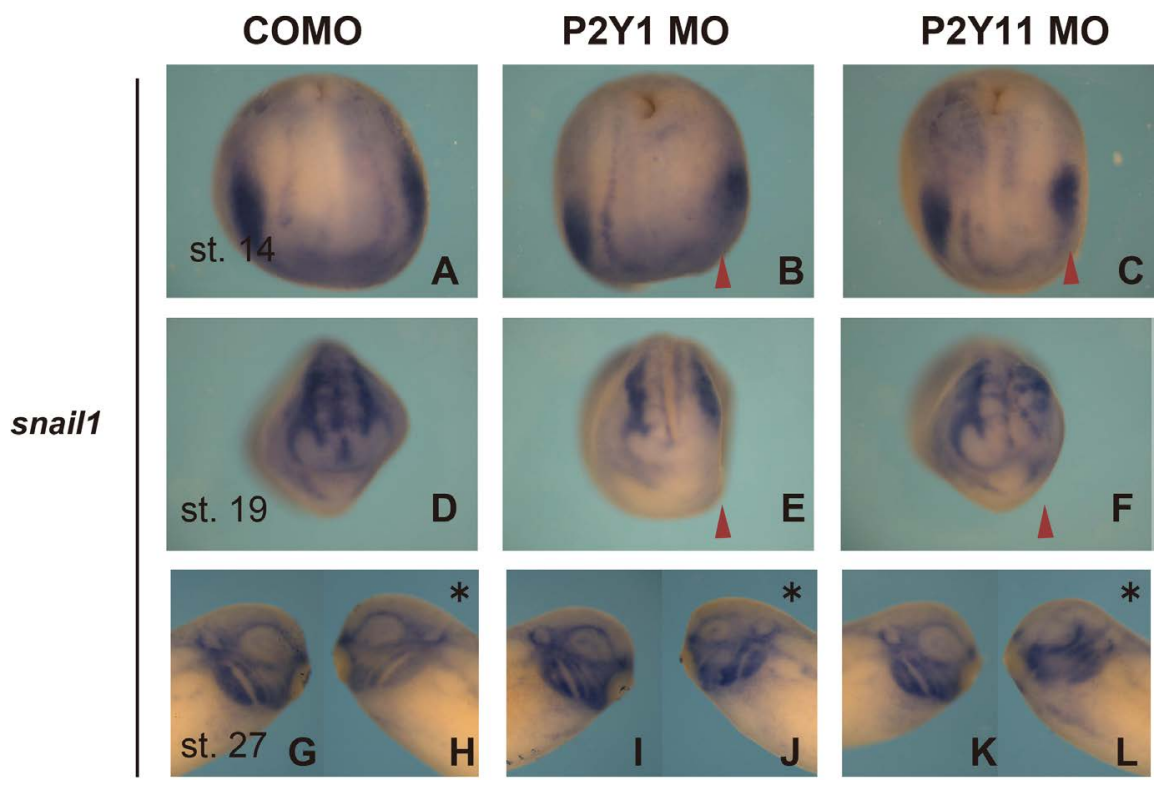

Figure 7. Depletion of $P 2 Y 1$ or $P 2 Y 11$ affects the neural crest development. Morpholino and YFP mRNA as a lineage tracer were coinjected into one dorsal animal blastomere of 8-cell stage. Embryos injected with COMO ((A), (D), (G), (H)), P2 Y1 MO ((B), (E), (I), $(\mathrm{J}))$ or $P 2 Y 11 \mathrm{MO}((\mathrm{C}),(\mathrm{F}),(\mathrm{K}),(\mathrm{L}))$ were analyzed for the expression of snaill at neurula and tailbud stages. Dorsal ((A), (B), (C)) views and anterior ((D), (E), (F)) with injected side facing rightwards. Lateral views $((\mathrm{G})-(\mathrm{L}))$. Red arrowheads indicate reduction of maker gene expression. Asterisk indicates injected side.

22, $P 2 Y 11 \mathrm{MO}: 28.6 \%, \mathrm{n}=28$, Figure 8(E) and Figure 8(F), red arrowheads) at the $P 2 Y 1$ or $P 2 Y 11 \mathrm{MO}$ injected side. $P 2 Y 1$ or $P 2 Y 11$ morphant also showed the "salt and pepper" pattern for epidermal marker expression in the neural plate. Taken together, these data suggest that the depletion of $P 2 Y 1$ or $P 2 Y 11$ may affect the induction and/or maintenance of neural tissue. Bone morphogenetic protein (BMP) signaling plays a role in epidermal fate establishment at the presumptive ectoderm, and BMP antagonists, such as Noggin, Chordin and Follistatin, induce neural tissue by antagonizing BMP activities [31] [32] [33]. P2 Y1 and $P 2 Y 11$ were expressed in the neural ectoderm, the endomesoderm and the involuting mesoderm (Figure 1, Figure 2). Thus, we speculated that $P 2 Y 1$ and $P 2 Y 11$ might be required for the establishment of the organizer and/or the competence of the ectoderm for neural induction.

Furthermore, we examined whether the observed effects of $P 2 Y 1$ or $P 2 Y 11$ knockdown might be attributed to an increase in the number of apoptotic cells. We performed TUNEL assay and found significant enhancement of apoptosis at neurula stage in embryos injected with $P 2 Y 1$ or $P 2 Y 11 \mathrm{MO}$ ( $P 2 Y 1 \mathrm{MO}: 42.9 \%, \mathrm{n}=$ 14, $P 2 Y 11$ MO: $100 \%, \mathrm{n}=10$, Figure $8(\mathrm{H})$ and Figure 8(I); $P 2 Y 1 \mathrm{MO}: 53.3 \%, \mathrm{n}=$ 15, P2 Y11 MO: 50\%, $\mathrm{n}=10$, Figure $8(\mathrm{~K})$ and Figure $8(\mathrm{~L})$ ), whereas COMO did not result in a significant enhancement of apoptosis in the injected side $(\mathrm{n}=11$, Figure $8(G) ; n=12$, Figure $8(J))$. However, the number of apoptotic cells was 


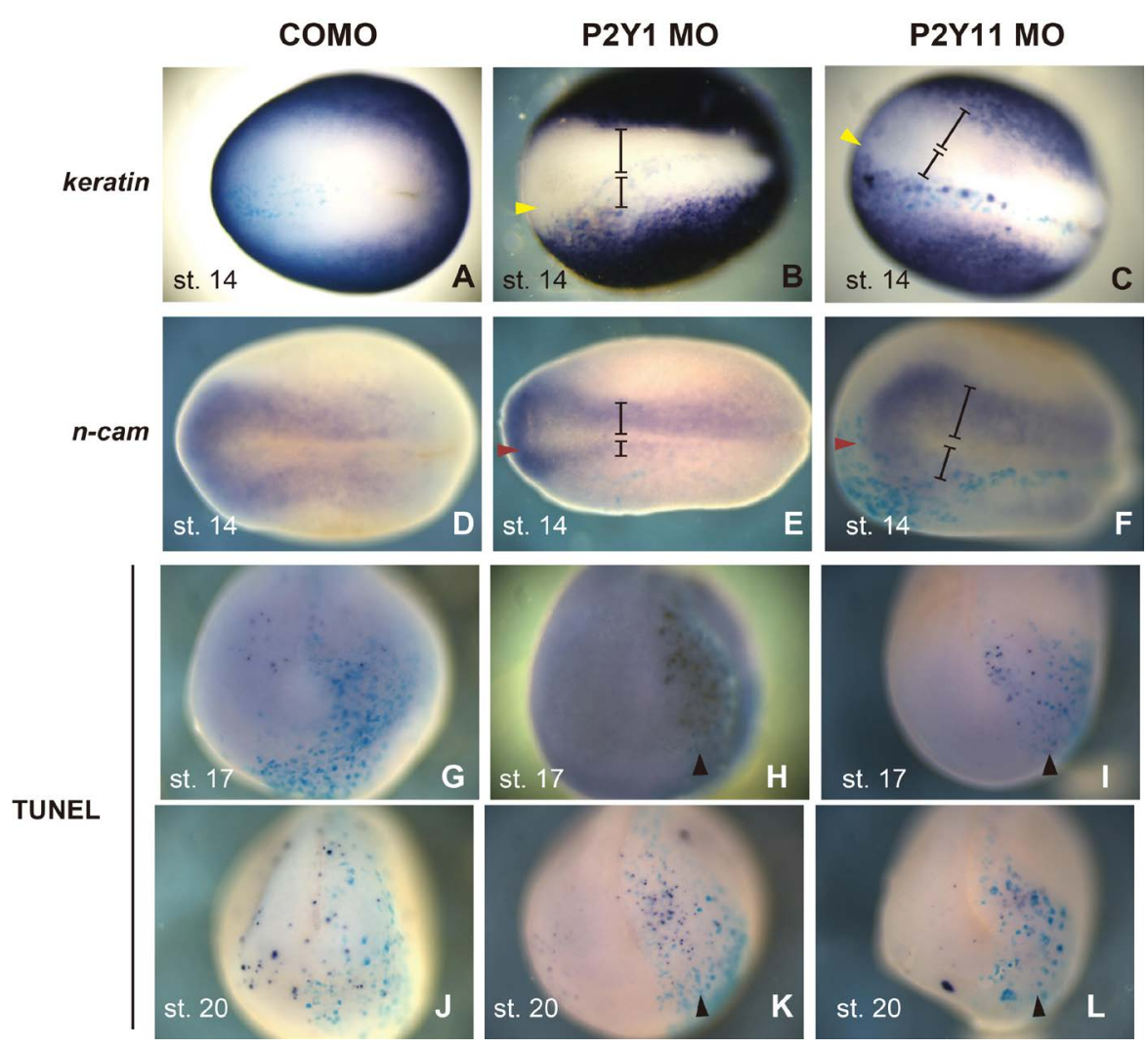

Figure 8. Depletion of $P 2 Y 1$ or $P 2 Y 11$ affected to the cell fate determination. COMO ((A), (D)), $P 2 Y 1 \mathrm{MO}((\mathrm{B})$, (E)) or $P 2 Y 11 \mathrm{MO}((\mathrm{C}),(\mathrm{F}))$ injected embryos were subjected to WISH to evaluate the expression of epi-keratin ((A)-(C)) and n-cam ((D)-(I)) at neurula stages. Epi-keratin expression expanded dorsally ((B), (C), yellow arrowheads) and the reduced width of $n$-cam expression was observed ((E), (F), red arrowheads) on the $P 2 Y 1 \mathrm{MO}$ or $P 2 Y 11 \mathrm{MO}$-injected side. TUNEL staining of COMO ((G), (J)), $P 2 Y 1 \mathrm{MO}$ ((I), (L)) or $P 2 Y 11 \mathrm{MO}((\mathrm{I}),(\mathrm{L}))$ injected embryos. A significant increase in the number of apoptotic cells were observed in the injected side with $P 2 Y 1 \mathrm{MO}((\mathrm{H}),(\mathrm{K})$, black arrowheads) or $P 2 Y 11 \mathrm{MO}((\mathrm{I})$, (L), black arrowheads) compared with uninjected side. Microinjection and lineage tracing were performed as described in Figure 3. Dorsal views with injected side (blue; X-gal) facing lower ((A)-(F)). Anterior views with injected side facing rightward $((\mathrm{G})-(\mathrm{L}))$. Black brackets indicate the width of neural plate.

not sufficient to allow interpretation of the observed phenotypes, and minimal apoptosis was detected at early neurulastage (data not shown). P2Y receptors increase intracellular $\mathrm{Ca}^{2+}$ concentration and modulate the intracellular environment as second messengers [34]. The increase in intracellular $\mathrm{Ca}^{2+}$ concentration is known to regulate cell proliferation, migration and differentiation in early development [35]. In fact, intracellular $\mathrm{Ca}^{2+}$ increase is induced in SCs of MOE through $P 2 Y 4$ receptors in $X$. laevis, and is involved in cell turnover [9] [10] [36]. It is also known that cell proliferation is essential for the induction and maintenance of neural crest cells [37], and $P 2 Y 1$ and $P 2 Y 11$ may maintain neural crest cells in proliferating and undifferentiated states. Although we could not entirely exclude the possibility that the depletion of $P 2 Y 1$ or $P 2 Y 11$ might di- 
rectly induce apoptosis, we considered that the significant increase in apoptosis at mid and late neurula stages might be due to reduced cell survival as development progressed.

In the present study, we revealed that $P 2 Y 1$ and $P 2 Y 11$ receptors were involved in $X$. laevis head formation. The knockdown approach revealed loss of neural development, suggesting that these receptors would be required for the induction and/or maintenance of neural tissues. As P2Y receptors in $X$. laevis have already been classified into six subtypes, the cellular and molecular functions of these receptors, including $P 2 Y 1$ or $P 2 Y 11$, should be studied further to fully understand the roles they play. The fact that P2Y receptors exist in only vertebrates and are highly conserved, and that $P 2 Y 1$ or $P 2 Y 11$ is involved in head formation has led us to expect that $\mathrm{P} 2 \mathrm{Y}$ receptors participate in the acquisition of vertebrate head during evolution. As only the physiological and pathophysiological functions of $\mathrm{P} 2 \mathrm{Y}$ receptors in the nervous system have been investigated, it is important to study further the roles of these receptors and their related molecules in early development.

\section{References}

[1] Burnstock, G. (2007) Physiology and Pathophysiology of Purinergic Neurotransmission. Physiological Reviews, 87, 659-797. https://doi.org/10.1152/physrev.00043.2006

[2] Burnstock, G. (2013) Purinergic Signalling: Pathophysiology and Therapeutic Potential. Keio Journal of Medicine, 62, 63-73.

[3] Abbracchio, M.P., Burnstock, G., Boeynaems, J.-M., Barnard, E.A., Boyer, J.L., Kennedy, C., et al. (2006) International Union of Pharmacology LVIII: Update on the P2Y G Protein-Coupled Nucleotide Receptors: From Molecular Mechanisms and Pathophysiology to Therapy. Pharmacological Reviews, 58, 281-341.

https://doi.org/10.1124/pr.58.3.3

[4] Abbracchio, M.P. and Ceruti, S. (2006) Roles of $\mathrm{P}_{2}$ Receptors in Glial Cells: Focus on Astrocytes. Purinergic Signalling, 2, 595-604.

https://doi.org/10.1007/s11302-006-9016-0

[5] Housley, G.D., Bringmann, A. and Reichenbach, A. (2009) Purinergic Signaling in Special Senses. Trends in Neurosciences, 32, 128-141.

https://doi.org/10.1016/j.tins.2009.01.001

[6] Masse, K., Bhamra, S., Eason, R., Dale, N. and Jones, E.A. (2007) Purine-Mediated Signalling Triggers Eye Development. Nature, 449, 1058-1062. https://doi.org/10.1038/nature06189

[7] Devader, C., Drew, C.M., Geach, T.J., Tabler, J., Townsend-Nicholson, A. and Dale, L. (2007) A Novel Nucleotide Receptor in Xenopus Activates the cAMP Second Messenger Pathway. FEBS Letters, 581, 5332-5336. https://doi.org/10.1016/j.febslet.2007.10.024

[8] Shindo, A., Hara, Y., Yamamoto, T.S., Ohkura, M., Nakai, J. and Ueno, N. (2010) Tissue-Tissue Interaction-Triggered Calcium Elevation Is Required for Cell Polarization during Xenopus Gastrulation. PLoS ONE, 5, e8897. https://doi.org/10.1371/journal.pone.0008897 
[9] Hassenklover, T., Kurtanska, S., Bartoszek, I., Junek, S., Schild, D. and Manzini, I. (2008) Nucleotide-Induced $\mathrm{Ca}^{2+}$ Signaling in Sustentacular Supporting Cells of the Olfactory Epithelium. Glia, 56, 1614-1624. https://doi.org/10.1002/glia.20714

[10] Dittrich, K., Sansone, A., Hassenklover, T. and Manzini, I. (2014) Purinergic Receptor-Induced $\mathrm{Ca}^{2+}$ Signaling in the Neuroepithelium of the Vomeronasal Organ of Larval Xenopus laevis. Purinergic Signaliling, 10, 327-336. https://doi.org/10.1007/s11302-013-9402-3

[11] Nieuwkoop, P.D. and Faber, J. (1967) Normal Table of Xenopus laevis (Daudin). North-Holland Publishing Company, Amsterdam.

[12] Sive, H.L., Grainger, R.M. and Harland, R.M. (1998) Early Development of Xenopus laevis. A Laboratory Manual. Cold Spring Harbor Laboratory Press, New York.

[13] Harland, R.M. (1991) Appendix G: In Situ Hybridization: An Improved WholeMount Method for Xenopus Embryos. Methods in Cell Biology, 36, 685-695. https://doi.org/10.1016/S0091-679X(08)60307-6

[14] Ermakova, G.V., Alexandrova, E.M., Kazanskaya, O.V., Vasiliev, O.L., Smith, M.W. and Zaraisky, A.G. (1999) The Homeobox Gene, Xanf-1, Can Control Both Neural Differentiation and Patterning in the Presumptive Anterior Neurectoderm of the Xenopus laevis Embryo. Development, 126, 4513-4523.

[15] Hemmati-Brivanlou, A., de la Torre, J.R., Holt, C. and Harland, R.M. (1991) Cephalic Expression and Molecular Characterization of Xenopus En-2. Development, $111,715-724$.

[16] Hirsch, N. and Harris, W.A. (1997) Xenopus Pax-6 and Retinal Development. Formerly Journal of Neurobiology, 32, 45-61. https://doi.org/10.1002/(SICI)1097-4695(199701)32:1<45::AID-NEU5>3.0.CO;2-E

[17] Kenyon, K.L., Moody, S.A. and Jamrich, M. (1999) A Novel Fork Head Gene Mediates Early Steps during Xenopus Lens Formation. Development, 126, 5107-5116.

[18] Ishibashi, S. and Yasuda, K. (2001) Distinct Roles of Maf Genes during Xenopus Lens Development. Mechanisms of Development, 101, 155-166. https://doi.org/10.1016/S0925-4773(00)00585-2

[19] Mathers, P.H., Grinberg, A., Mahon, K.A. and Jamrich, M. (1997) The $R x$ Homeobox Gene Is Essential for Vertebrate Eye Development. Nature, 387, 603-607. https://doi.org/10.1038/42475

[20] Luo, T., Matsuo-Takasaki, M. and Sargent, T.D. (2001) Distinct Roles for Distal-Less Genes Dlx 3 and Dlx 5 in Regulating Ectodermal Development in Xenopus. Molecular Reproduction and Development, 60, 331-337. https://doi.org/10.1002/mrd.1095

[21] Bourguignon, C., Li, J. and Papalopulu, N. (1998) XBF-1, a Winged Helix Transcription Factor with Dual Activity, Has a Role in Positioning Neurogenesis in $\mathrm{Xe}$ nopus Competent Ectoderm. Development, 125, 4889-4900.

[22] Zuber, M.E., Perron, M., Philpott, A., Bang, A. and Harris, W.A. (1999) Giant Eyes in Xenopus laevis by Overexpression of XOptx2. Cell, 98, 341-352. https://doi.org/10.1016/S0092-8674(00)81963-7

[23] Nieto, M.A., Bradley, L.C. and Wilkinson, D.G. (1991) Conserved Segmental Expression of Krox-20 in the Vertebrate Hindbrain and Its Relationship to Lineage Restriction. Development, 2, 59-62.

[24] Kintner, C.R. and Melton, D.A. (1987) Expression of Xenopus N-CAM RNA in Ectoderm Is an Early Response to Neural Induction. Development, 99, 311-325. 
[25] Blitz, I.L. and Cho, K.W. (1995) Anterior Neurectoderm Is Progressively Induced during Gastrulation: The Role of the Xenopus Homeobox Gene Orthodenticle. Development, 121, 993-1004.

[26] Masse, K., Eason, R., Bhamra, S., Dale, N. and Jones, E.A. (2006) Comparative Genomic and Expression Analysis of the Conserved NTPDase Gene Family in Xenopus. Genomics, 87, 366-381. https://doi.org/10.1016/j.ygeno.2005.11.003

[27] Ermakova, G.V., Solovieva, E.A., Martynova, N.Y. and Zaraisky, A.G. (2007) The Homeodomain Factor Xanf Represses Expression of Genes in the Presumptive Rostral Forebrain That Specify More Caudal Brain Regions. Developmental Biology, 307, 483-497. https://doi.org/10.1016/j.ydbio.2007.03.524

[28] Kazanskaya, O.V., Severtzova, E.A., Barth, K.A., Ermakova, G.V., Lukyanov, S.A., Benyumov, A.O., et al. (1997) Anf. A Novel Class of Vertebrate Homeobox Genes Expressed at the Anterior End of the Main Embryonic Axis. Gene, 200, 25-34. https://doi.org/10.1016/S0378-1119(97)00326-0

[29] Zaraisky, A.G., Ecochard, V., Kazanskaya, O.V., Lukyanov, S.A., Fesenko, I.V. and Duprat, A.M. (1995) The Homeobox-Containing Gene XANF-1 May Control Development of the Spemann Organizer. Development, 121, 3839-3847.

[30] Zygar, C.A., Cook, T.L. and Grainger Jr., R.M. (1998) Gene Activation during Early Stages of Lens Induction in Xenopus. Development, 125, 3509-3519.

[31] Smith, W.C. and Harland, R.M. (1992) Expression Cloning of Noggin, a New Dorsalizing Factor Localized to the Spemann Organizer in Xenopus Embryos. Cell, 70, 829-840. https://doi.org/10.1016/0092-8674(92)90316-5

[32] Sasai, Y., Lu, B., Steinbeisser, H., Geissert, D., Gont, L.K. and De Robertis, E.M. (1994) Xenopus Chordin: A Novel Dorsalizing Factor Activated by Organizer-Specific Homeobox Genes. Cell, 79, 779-790. https://doi.org/10.1016/0092-8674(94)90068-X

[33] Fainsod, A., Deißler, K., Yelin, R., Marom, K., Epstein, M., Pillemer, G., Steinbeisser, H. and Blum, M. (1997) The Dorsalizing and Neural Inducing Gene Follistatin Is an Antagonist of BMP-4. Mechanisms of Development, 63, 39-50. https://doi.org/10.1016/S0925-4773(97)00673-4

[34] Bogdanov, Y.D., Dale, L., King, B.F., Whittock, N. and Burnstock, G. (1997) Early Expression of a Novel Nucleotide Receptor in the Neural Plate of Xenopus Embryos. The Journal of Biological Chemistry, 272, 12583-12590. https://doi.org/10.1074/jbc.272.19.12583

[35] Lauder, J.M. (1993) Neurotransmitters as Growth Regulatory Signals: Role of Receptors and Second Messengers. Trends in Neurosciences, 16, 233-240. https://doi.org/10.1016/0166-2236(93)90162-F

[36] Hassenklover, T., Schwartz, P., Schild, D. and Manzini, I. (2009) Purinergic Signaling Regulates Cell Proliferation of Olfactory Epithelium Progenitors. Stem Cells, 27, 2022-2031. https://doi.org/10.1002/stem.126

[37] Nagatomo, K. and Hashimoto, C. (2007) Xenopus Hairy2 Functions in Neural Crest Formation by Maintaining Cells in a Mitotic and Undifferentiated State. Developmental Dynamics, 236, 1475-1483. https://doi.org/10.1002/dvdy.21152 
Submit or recommend next manuscript to SCIRP and we will provide best service for you:

Accepting pre-submission inquiries through Email, Facebook, LinkedIn, Twitter, etc. A wide selection of journals (inclusive of 9 subjects, more than 200 journals)

Providing 24-hour high-quality service

User-friendly online submission system

Fair and swift peer-review system

Efficient typesetting and proofreading procedure

Display of the result of downloads and visits, as well as the number of cited articles Maximum dissemination of your research work

Submit your manuscript at: http://papersubmission.scirp.org/

Or contact cellbio@scirp.org 